\title{
PERANCANGAN DAN PENGUJIAN KINERJA MESIN PENCACAH TULANG IKAN
}

\section{Design and Performance Test of Fish Bone Chopping Machine}

\author{
Wahyu Tri Handoyo*, Luthfi Assadad, dan Bakti Berlyanto Sedayu \\ Loka Riset Mekanisasi Pengolahan Hasil Perikanan, JI. Imogiri Barat KM. 11.5, Jetis, Bantul - DI Yogyakarta, Indonesia \\ *Korespondensi Penulis: wahzu.th@gmail.com
}

Diterima: 10 Januari 2020; Direvisi: 24 Maret 2020; Disetujui: 1 Mei 2020

\begin{abstract}
ABSTRAK
Tepung ikan merupakan salah satu komoditas penting akuakultur yang permintaannya di Indonesia meningkat setiap tahun seiring pesatnya perkembangan akuakultur. Sebagian besar kebutuhan tepung ikan tersebut dipenuhi dari impor. Salah satu upaya untuk mengurangi kebutuhan impor adalah memanfaatkan berbagai jenis ikan rucah dan sisa olahan ikan berupa tulang dan kepala ikan sebagai bahan baku tepung ikan. Permasalahan yang dihadapi pada pengolahan tulang ikan adalah proses pencacahan menjadi ukuran yang lebih kecil. Oleh karena itu diperlukan mesin yang mampu mencacah tulang ikan yang memiliki tekstur keras. Telah dilakukan perancangan, pembuatan dan pengujian kinerja mesin pencacah tulang ikan. Mesin dirancang berdasarkan mekanisme kerja poros berputar untuk menggerakkan sepasang mata pisau yang saling berhimpitan dan berputar berlawanan arah. Uji kinerja dilakukan dengan beban tulang ikan tuna dengan variasi perlakuan frekuensi inverter 25; 37,5; dan $50 \mathrm{~Hz}$. Parameter yang diamati meliputi rendemen, kecepatan putaran poros, waktu pencacahan, dan kapasitas pencacahan. Hasil uji coba menunjukkan bahwa semakin tinggi frekuensi inverter, kecepatan putaran poros semakin tinggi, sehingga kapasitas pencacahan semakin meningkat. Berdasarkan parameter yang diamati, mesin bekerja optimal pada frekuensi inverter $50,0 \mathrm{~Hz}$.
\end{abstract}

KATA KUNCI : tepung ikan, tulang ikan, pencacahan, perancangan, pengujian kinerja

\begin{abstract}
Fish meal is one of the essential inputs for aquaculture, and the demand in Indonesia is growing every year parallel with the rapid development of aquaculture. Most of the fish meal was imported. An effort to reduce imports is to utilize various types of trash fish and fish processing waste, including bones and head as raw material for fish meal. The problem that occurs in the processing of fish bone is the process of chopping them into smaller sizes. Therefore, a machine capable of chopping hard texture of fish bones is needed. The design and performance tests of the fish bone chopping machine have been conducted. The device was designed based on the working mechanism of the rotating shaft to drive the paired blades that coincide and rotate in the opposite direction. The performance test was carried out for tuna bone with varied inverter frequencies of 25; 37,5; and $50 \mathrm{~Hz}$. The parameters observed were yield, shaft speed, chopping time, and capacity. The results showed that increasing inverter frequency increased the shaft speed; therefore, it increased the capacity. Based on the observed parameters, the machine worked optimally at an inverter frequency of $50,0 \mathrm{~Hz}$.
\end{abstract}

KEYWORDS: fish meal, fish bone, chopping, design, performance test

\section{PENDAHULUAN}

Tepung ikan merupakan salah satu komoditas penting perikanan di Indonesia. Kebutuhan tepung ikan di Indonesia sangat besar, dengan jumlah permintaan berkisar antara 150.000-200.000 ton per tahun dan cenderung mengalami peningkatan setiap tahun
(Kusumo, 2012; Nurhayat, 2013; Poernomo, 2013). Nainggolan et al. (2017) menyatakan bahwa sejauh ini kebutuhan tepung ikan di Indonesia dipenuhi dari impor dengan volume impor tertinggi sebesar 186.601 ton pada tahun 2013.

Berbagai upaya telah dilakukan untuk mengurangi ketergantungan impor tepung ikan. Salah satu di 
antaranya yaitu berupa pemanfaatan berbagai jenis ikan rucah maupun sisa olahan ikan yang tidak terpakai berupa tulang dan kepala ikan sebagai bahan baku tepung ikan (Assadad, Hakim, \& Widianto, 2015; Handoyo \& Assadad, 2016; Mahendra, Assadad, \& Zulfia, 2015). Upaya lain yang dilakukan yaitu dengan merancang dan mengembangkan berbagai peralatan untuk pengolahan tepung ikan. Kementerian Kelautan dan Perikanan sejauh ini telah memberikan banyak peralatan pengolahan tepung ikan kepada pelaku usaha perikanan di berbagai daerah (KKP, 2017; KKP, 2018). Namun demikian peralatan ini dikhususkan untuk penggunaan bahan baku yang berasal dari ikanikan rucah non ekonomis berukuran kecil sehingga akan mengalami kendala jika bahan baku berasal dari tulang atau kepala ikan yang memiliki tekstur keras dan berukuran besar.

Potensi sisa olahan ikan dan ikan rucah sebagai sumber bahan baku tepung ikan tersedia cukup melimpah. Beberapa lokasi yang memiliki sumber bahan baku tulang ikan diantaranya yaitu di kabupaten Pacitan dan Gunungkidul yang memiliki industri tahu tuna. Tulang dan kepala ikan tuna sisa pembuatan tahu tuna yang tidak termanfaatkan dapat dijadikan sebagai sumber bahan baku untuk pembuatan tepung ikan (Assadad, Hakim, \& Widianto, 2015). Di desa Regemuk kecamatan Pantai Labu kabupaten Deli Serdang tersedia bahan baku untuk tepung ikan dari hasil samping tangkapan ikan dan sisa olahan ikan. Cukup sering dan tidak sedikit ditemui hasil tangkapan ikan yang tidak diminati oleh konsumen menjadi limbah ikan yang tidak termanfaatkan. Selain itu sisa olahan pembuatan bakso juga belum termanfaatkan (Berutu, Hidayat, Syahputra, \& Harefa, 2018). Di kabupaten Sumenep yang merupakan salah satu sentra perikanan di Madura memiliki sumber bahan baku tepung ikan dari sisa hasil olahan UKM kerupuk dan hasil tangkapan samping di komunitas nelayan TPI. Sisa hasil olahan ikan dan hasil tangkapan samping tersebut belum dimanfaatkan sehingga hanya menjadi limbah yang mencemari lingkungan (Khotimah \& Haryanto, 2017). Kota Palembang yang memiliki makanan tradisional berbahan baku ikan juga menghasilkan limbah dan sisa pengolahan berupa tulang, kepala dan sirip ikan yang juga dapat dimanfaatkan sebagai bahan baku pembuatan tepung ikan (Harris, Efreza, \& Nafsiyah, 2011).

Pada proses pembuatan tepung ikan dengan bahan baku tulang dan kepala ikan diperlukan proses pendahuluan berupa pencacahan material untuk memperkecil ukuran, sebelum diproses lebih lanjut. Pencacahan material ini dapat dilakukan dengan peralatan pencacah (chopper). Berbagai penelitian untuk mengkaji, merancang dan mengembangkan peralatan pencacah untuk berbagai produk maupun hasil samping produk pertanian secara luas telah banyak dilakukan. Misalnya perancangan alat pencacah buah sukun (Weiss, George, \& Walker, 2006), perancangan alat pencacah biji jarak (Ting, Casas, Peralta, \& Elauria, 2012), perancangan alat pencacah tandan kosong kelapa sawit (Junaidi, Kasim, Zamri, \& Anderson, 2014), perancangan alat pencacah kompos (Hande \& Deshpande, 2014; Kumar \& Kumar, 2015), dan perancangan alat pencacah rumput laut (Pradana, 2015). Sejauh ini berdasarkan penelusuran, belum ditemukan alat pencacah untuk spesifik bahan baku tulang dan kepala ikan. Penelitian ini bertujuan untuk merancang dan membuat mesin pencacah tulang ikan serta melakukan pengujian kinerja.

\section{BAHAN DAN METODE}

\section{Bahan dan Alat}

Bahan yang dipergunakan untuk pembuatan mesin pencacah tulang ikan yaitu motor listrik 3 phase, 220 V/380 V, 50 Hz, 2 HP; gear box dengan rasio 1:30; coupling; hollow SS 304; pipa SS 304; bearing; roda gigi kontra; baut SS 304; round bar SS 304 dan SKD 11. Peralatan yang digunakan untuk pembuatan mesin yaitu mesin bubut, mesin las, alat penekuk, gergaji potong, gerinda, mesin bor, mesin tap dan peralatan bengkel lainnya. Peralatan bantu yang digunakan untuk uji coba yaitu bak penampung bahan baku dan penampung hasil pencacahan, timbangan, tachometer dan stop watch.

Bahan baku yang digunakan untuk uji coba yaitu tulang ikan tuna yang berasal dari hasil samping pengolahan produk tahu tuna di kabupaten Pacitan. Ukuran kepala dan tulang ikan yang digunakan adalah kepala ikan dengan panjang sekitar $15 \mathrm{~cm}$, lebar 8 $\mathrm{cm}$ dan tebal $5 \mathrm{~cm}$.

\section{Metode}

Penelitian ini mencakup tahap perancangan, fabrikasi dan perakitan, dan uji kinerja mesin. Perancangan mesin pencacah diawali dengan membuat konsep desain dengan sistem berkelanjutan dan mudah dioperasikan. Selanjutnya dibuat detail desain tiap komponen mesin yang dituangkan dalam gambar teknik. Setelah konsep dan gambar teknik sesuai dengan yang diharapkan, selanjutnya masuk pada tahapan pembuatan mesin. Tahapan pembuatan melalui serangkaian proses fabrikasi dan perakitan. Setelah selesai dirakit, mesin kemudian diuji kinerjanya baik tanpa beban maupun dengan beban. Alur penelitian disajikan dalam diagram alir seperti pada Gambar 1. 


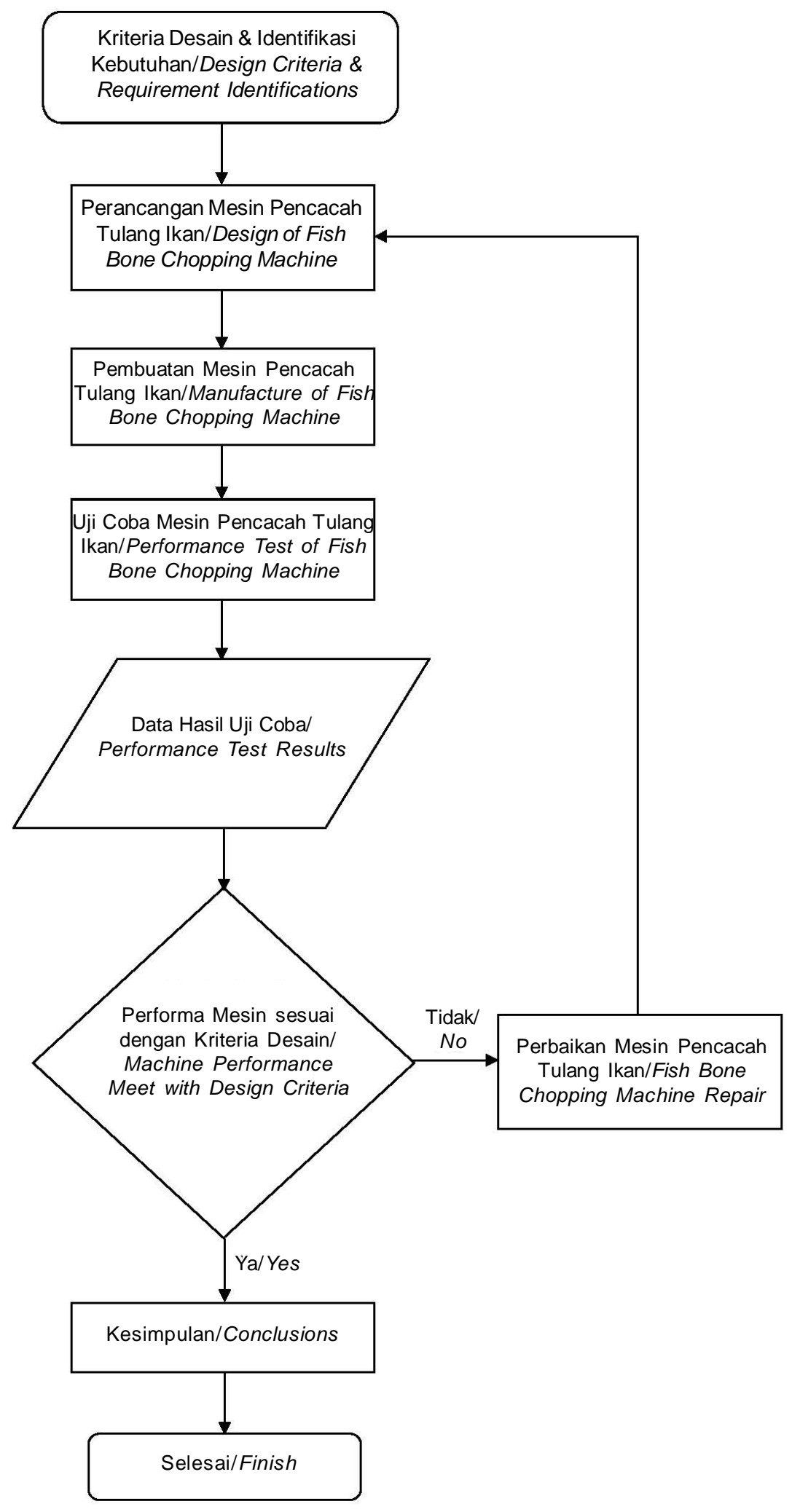

Gambar 1. Diagram alir perancangan, pembuatan dan uji kinerja mesin pencacah tulang ikan Figure 1. Flowchart of design, manufacture and performance test of fish bone chopping machine 


\section{Kriteria desain}

Mesin pencacah dirancang untuk mencacah material bahan baku tepung ikan berupa tulang dan kepala ikan berukuran besar dan keras. Hasil yang diharapkan adalah cacahan dengan ukuran lebih kecil $(2-3 \mathrm{~cm})$, disesuaikan dengan mesin grinderyang akan digunakan untuk proses selanjutnya. Sistem kerja mesin pencacah dibuat sederhana sehingga mudah dioperasikan oleh operator di unit pengolahan. Kapasitas yang diharapkan adalah $500 \mathrm{~kg} / \mathrm{jam}$ untuk dapat memenuhi kebutuhan bahan baku tepung ikan. Kapasitas pencacahan tersebut berdasarkan hasil identifikasi kebutuhan dari pengolah tepung ikan di kabupaten Gunungkidul, Wonogiri dan Pacitan.

\section{Rancangan fungsional}

Rangka dan meja merupakan dudukan untuk menempatkan motor penggerak, sistem transmisi dan seperangkat alat pencacah sehingga harus mampu menahan beban dan getaran yang timbul selama mesin beroperasi. Pada rancangan ini perhitungan getaran tidak dilakukan. Getaran ditimbulkan karena putaran komponen-komponen mesin dan tumbukan antara pisau pencacah dan bahan baku. Sistem transmisi menggunakan kopel menjadi lebih efektif dan akan mengurangi komponen yang berputar dan saling bergesekan sehingga diharapkan dapat mengurangi getaran yang terjadi saat mesin beroperasi. Selain itu kaki rangka bentuk jack tanpa roda diharapkan juga dapat mengurangi getaran yang terjadi. Hopper (bagian input) berfungsi sebagai tempat memasukkan bahan baku berupa tulang dan kepala ikan yang akan dicacah. Pisau (blade) yang terpasang pada poros merupakan komponen utama yang berfungsi untuk mencacah dan didukung oleh sisir yang berfungsi untuk menyisir atau membersihkan pisau dari bahan baku yang masih menempel. Outlet merupakan tempat keluaran produk yang telah dicacah. Motor listrik berfungsi sebagai penggerak pisau pencacah. Motor listrik dan pisau pencacah dihubungkan dengan kopel yang berfungsi untuk menghubungkan dan mentransmisikan daya dan putaran motor ke pisau pencacah. Ditambahkan sepasang roda gigi supaya sepasang pisau berputar berlawanan arah dan juga dipasang gear reducer untuk mereduksi kecepatan putaran motor. Sedangkan untuk mengatur kecepatan putaran motor digunakan inverter. Rancangan fungsional mesin pencacah tulang ikan ditabulasi dan disajikan pada Tabel 1.

\section{Rancangan struktural}

Rangka dan meja terbuat dari plat SS 304 dengan ketebalan 1,2 $\mathrm{mm}$ dan terdiri dari meja dengan 4 (empat) kaki yang berfungsi untuk menopang komponen mesin pencacah. Hopper terbuat dari plat

Tabel 1. Rancangan fungsional mesin pencacah tulang ikan

Table 1. Functional design of fish bone chopping machine

\begin{tabular}{ll}
\hline Bagian Mesin/Machine Parts & \multicolumn{1}{c}{ Fungsi/Functions } \\
\hline Hopper/Hopper & $\begin{array}{l}\text { Tempat masukan bahan baku tulang dan kepala ikan yang akan } \\
\text { dicacah/A place to input of raw materials of bone and fish head to be } \\
\text { chopped } \\
\text { Komponen utama untuk mencacah bahan baku/Main component for } \\
\text { chopping a raw materials } \\
\text { Pisau/Blade }\end{array}$ \\
Membersinkan pisau dari bahan baku yang menempel/Clean up the \\
blade from raw materials residue
\end{tabular}


SS 304 dengan ketebalan 1,2 mm. Konstruksi Hopper dibuat bentuk trapesium dengan sisi atas lebih luas dan menyempit pada sisi bawah. Konstruksi tersebut diharapkan dapat memudahkan ketika memasukkan bahan baku dan dapat mengarahkan ke bagian pisau pencacah. Pisau pencacah terdiri dari 18 pisau yang terbuat dari material SKD 11 yang diberi perlakuan hardening sampai $60 \mathrm{HRC}$ dan dipasang pada dua poros, di mana pada masing-masing poros terdapat 9 pisau. Konstruksi pisau berupa tabung tipis yang diberi kontur supaya dapat menarik bahan baku yang masuk. Motor penggerak yang digunakan yaitu motor listrik 3 phase, 220 V/380 V, 2 HP. Kontrol panel dipasang untuk sentralisasi sistem kelistrikan supaya memudahkan pengoperasian dan keamanan operasional mesin.

\section{Uji Kinerja Mesin}

Uji kinerja dilakukan dengan memberikan beban terhadap mesin, yaitu berupa bahan baku tulang ikan tuna. Perlakuan yang diberikan adalah variasi frekuensi inverteryaitu $25,37,5$ dan $50 \mathrm{~Hz}$. Parameter yang diamati meliputi rendemen, kecepatan putara poros, waktu pencacahan, dan kapasitas pencacahan.

\section{Rendemen}

Rendeman hasil proses dihitung sebagai persentase bobot produk $(\mathrm{kg})$ yang keluar dari mesin pencacah tulang ikan terhadap bobot bahan baku awal (kg) (Sedayu, Erawan, \& Utomo, 2013). Dituliskan dalam persamaan sebagai berikut:

Rendemen $(\%)=\frac{\text { Bobot produk }(\mathrm{kg})}{\text { Bobot bahan baku }} \times 100 \%$.......(1) $(\mathrm{kg})$

Input bahan baku kepala dan tulang ikan dengan ukuran panjang sekitar $15 \mathrm{~cm}$, lebar $8 \mathrm{~cm}$ dan tebal 6 $\mathrm{cm}$. Ukuran tersebut tidak bisa menjadi acuan baku, tetapi ukuran tersebut adalah ukuran bahan baku ratarata yang digunakan untuk uji coba. Output berupa cacahan tulang dan kepala ikan dengan ukuran kurang dari 2-3 cm yang bisa diproses selanjutnya pada mesin grinder.

\section{Kecepatan putaran poros}

Kecepatan putaran poros (rpm) diukur dengan menggunakan tachometer dengan titik pengukuran pada poros motor listrik. Kecepatan putaran motor induksi sendiri dipengaruhi oleh frekuensi masukan (f) dan jumlah kutub motor (p) seperti ditunjukkan pada persamaan berikut ini:

$n_{s}=\frac{120 . f}{p}$
Persamaan 2 menunjukkan bahwa frekuensi masukan (f) berbanding lurus dengan putaran motor $\left(n_{s}\right)$. Oleh karena itu semakin besar nilai frekuensi inverter maka semakin besar pula putaran motor yang dihasilkan. Sedangkan untuk daya motor (P) ditentukan oleh besarnya torsi $(\tau)$ dan putaran atau kecepatan sudut $(\omega)$ seperti ditunjukkan pada persamaan berikut ini:

$P=\tau \times \omega$

\section{Waktu pencacahan}

Waktu pencacahan (detik) dihitung dengan menggunakan stopwatch untuk input bahan baku dengan bobot yang sama.

\section{Volume hopper}

Volume hopper dihitung menggunakan metode dengan membagi hopper menjadi beberapa bangun ruang, yaitu terdiri dari 3 balok, 4 prisma dan 4 limas segi empat. Persamaan yang digunakan untuk menghitung bangun ruang, yaitu:

$$
\begin{aligned}
& V_{1}=P \times L \times T \\
& V_{2}=\text { Luas alas } \times T \\
& V_{3}=\frac{1}{3} \times P \times L \times T
\end{aligned}
$$

\section{Kapasitas pencacahan}

Kapasitas pencacahan $(\mathrm{kg} / \mathrm{jam})$ ditentukan sebagai perbandingan antara bobot produk $(\mathrm{kg})$ yang ke luar dari mesin pencacah tulang ikan terhadap waktu yang digunakan untuk mencacah (jam) (Hidayat, Harjono, Marsudi, \& Gunanto, 2006). Dituliskan dalam persamaan sebagai berikut:

$$
\begin{gathered}
\text { Kapasitas pencacahan } \\
(\mathrm{kg} / \mathrm{jam})
\end{gathered}=\frac{\text { Bobot produk }(\mathrm{kg})}{\begin{array}{c}
\text { Waktu pencacahan } \\
(\text { jam })
\end{array}}
$$

\section{HASIL DAN PEMBAHASAN}

\section{Desain dan Konstruksi Mesin}

Mesin pencacah tulang ikan yang dirancang bangun ini mengadopsi mesin shredder untuk mencacah sampah plastik pada proses daur ulang plastik dalam manajemen sampah plastik (David \& Joel, 2018). Rancang bangun yang sama juga dilakukan oleh Jadhav et al. (2018) yang juga melakukan desain dan pengembangan mesin shredder untuk mencacah sampah botol plastik. Desain pisau mesin shredder tersebut memiliki konsep dan mekanisme penghancuran dan pencacahan yang 
baik, bahan baku akan secara otomatis tertarik dan tercacah dengan efektif. Oleh karena itu desain pisau shredder tersebut dipilih untuk digunakan sebagai mesin pencacah tulang dan kepala ikan.

Mesin pencacah tulang ikan terdiri atas bagian pisau pencacah, bagian input material, bagian output material, rangka dan meja utama, motor penggerak dan bagian transmisi, dan kontrol panel. Pisau pencacah terdiri dari 18 pisau dan dipasang pada dua poros sehingga pada masing-masing poros terdapat 9 pisau. Pisau berupa silinder pejal dengan ketebalan $10 \mathrm{~mm}$ dan diameter $100 \mathrm{~mm}$, dan terdapat tiga kontur sebagai mata pisau sebagaimana disajikan pada Gambar 2. Material pisau terbuat dari SKD 11 yang diberi perlakuan pengerasan (harden) sehingga memiliki kekerasan sampai dengan $60 \mathrm{HRC}$.

Hopper dibuat bentuk trapesium dengan sisi atas lebih luas dan menyempit pada sisi bawah supaya memudahkan dalam memasukkan material tulang dan kepala ikan. Material hopper terbuat dari plat SS 304 dengan ketebalan 1,2 $\mathrm{mm}$ dan dibentuk trapesium dengan ukuran panjang (P) $960 \mathrm{~mm}$, lebar (L) 750 $\mathrm{mm}$, dan tinggi (T) $250 \mathrm{~mm}$. Sedangkan pada bagian output dibuat seperti diffuser untuk mengarahkan material hasil cacahan supaya mudah masuk kedalam bak penampung. Material yang digunakan adalah plat SS 304 dengan tebal 1,2 mm. Rangka dan meja terbuat dari plat SS 304 dengan ketebalan 1,2 mm dan terdiri dari meja dengan 4 (empat) kaki yang berfungsi untuk menopang komponen mesin pencacah. Dimensi keseluruhan rangka dan meja adalah panjang (P) $1500 \mathrm{~mm}$, lebar (L) $830 \mathrm{~mm}$ dan tinggi (T) $750 \mathrm{~mm}$ sebagaimana disajikan pada Gambar 3.

Motor penggerak yang digunakan yaitu unit motor listrik 3 phase, $220 \mathrm{~V} / 380 \mathrm{~V}, 50 \mathrm{~Hz}, 2 \mathrm{HP}$. Untuk

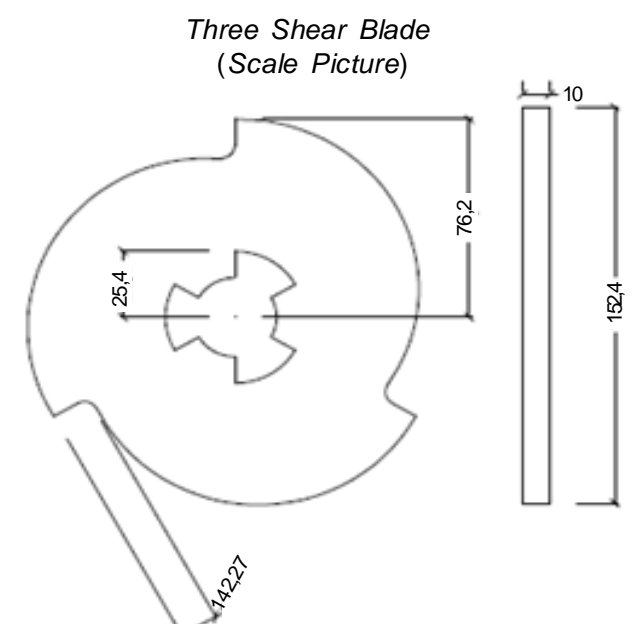

Gambar 2. Desain pisau mesin pencacah tulang ikan

Figure 2. Blade design of fish bone chopping machine

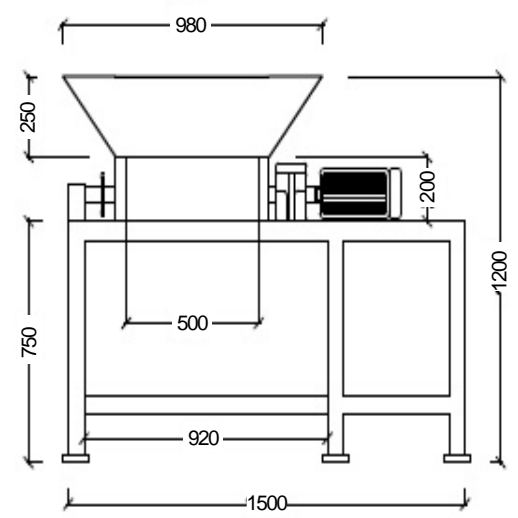

Tampak depan/Front view

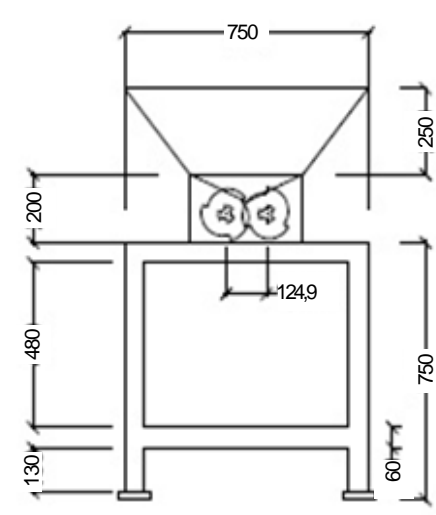

Tampak samping/Side view

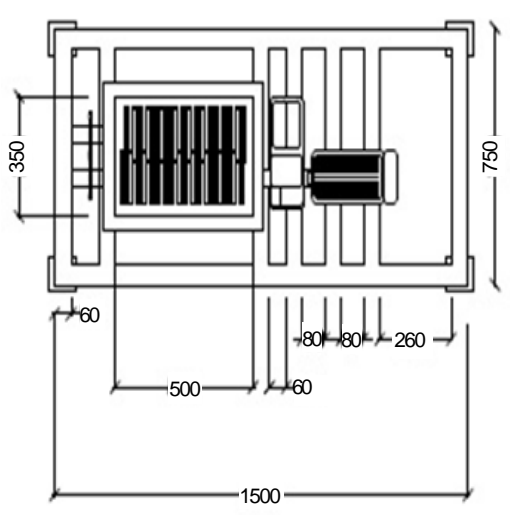

Tampak atas/Top view

Gambar 3. Desain mesin pencacah tulang ikan

Figure 3. Design of fish bone chopping machine 


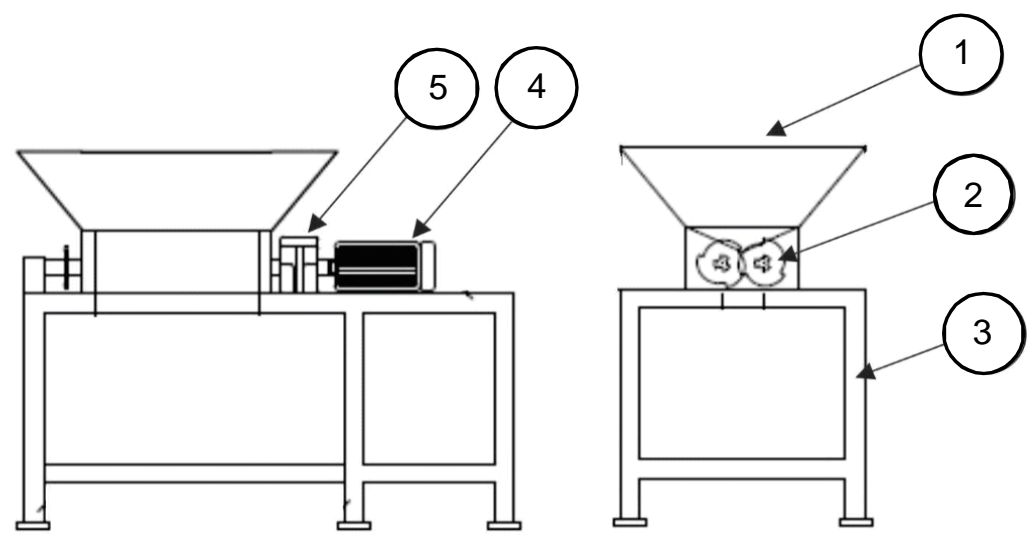

Keterangan/Note:

1: Pengumpan/Hopper

2: Pisau pencacah/Chopper blade

3: Rangka dan meja/Frame and table

4: Motor penggerak/Motor drive

5: Sepasang roda gigi dan kopel/Gear set and coupling

Gambar 4. Bagian utama mesin pencacah tulang ikan

Figure 4. Main part of fish bone chopping machine

memperoleh kecepatan putar lebih lambat dengan torsi maksimal, ditambahkan gear reducer dengan rasio1:30. Untuk meneruskan daya dari poros gear reducerke pisau pencacah digunakan coupling. Untuk menggerakkan 2 poros pisau pencacah supaya berlawanan arah digunakan sepasang roda gigi sebagaimana disajikan pada Gambar 4. Tampilan fisik mesin pencacah tulang ikan disajikan pada Gambar 5 , dengan spesifikasi mesin yang telah dirancang disajikan pada Tabel 2.
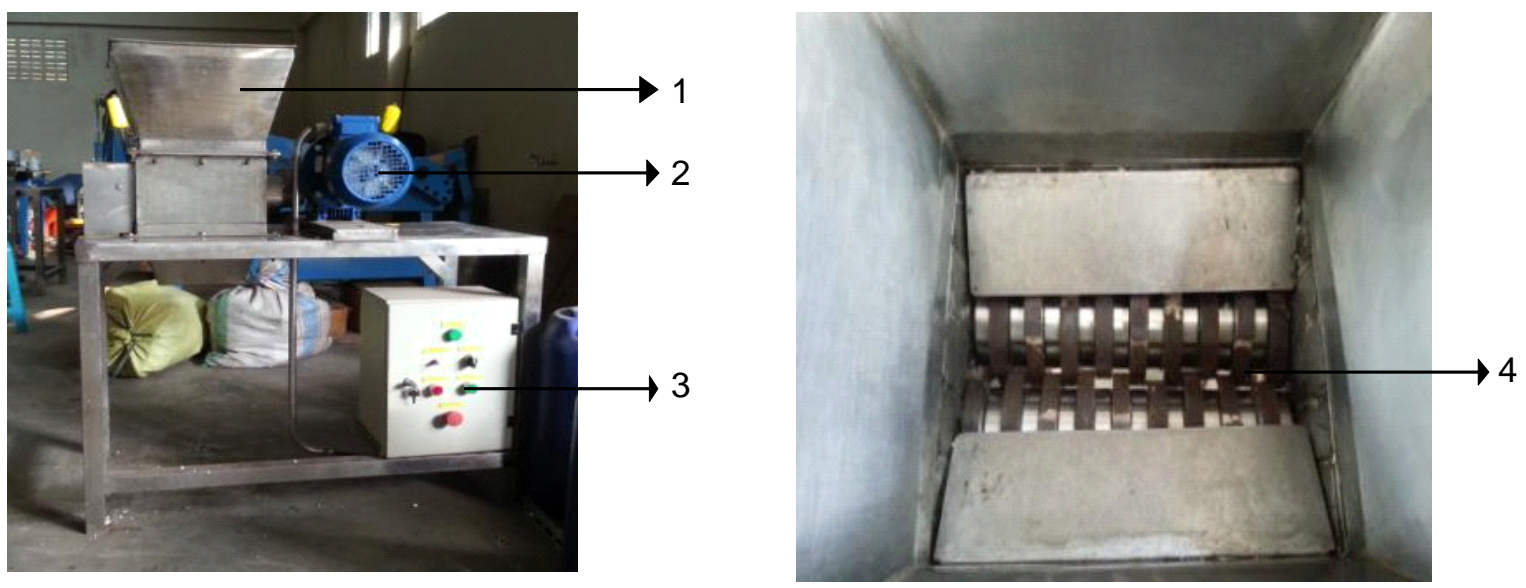

Keterangan/Note :

1: Pengumpan/Hopper

2: Motor penggerak/Motor drive

3: Panel kontrol/Control panel

4: Mata pisau ganda/Double blade

Gambar 5. Mesin pencacah tulang ikan

Figure 5. Fish bone chopping machine 
Tabel 2. Spesifikasi teknis mesin pencacah tulang ikan

Table 2. Technical specifications of fish bone chopping machine

\begin{tabular}{lc}
\hline \multicolumn{1}{c}{ Nama/Names } & Spesifikasi/Specifications \\
\hline Sistem mesin/Machine system & Berkelanjutan/Continue \\
Spesifikasi motor/ Motor Specifications & 3 phase, 220 V/380 V 50 Hz, 2 HP \\
Spesifikasi reducer/Reducer specifications & $1: 30$ \\
Dimensi Total/Total dimensions: & \\
- Panjang/Length $(\mathrm{mm})$ & 1500 \\
- Lebar/Width $(\mathrm{mm})$ & 830 \\
- Tinggi/Height $(\mathrm{mm})$ & 1200 \\
\hline
\end{tabular}

\section{Mekanisme Kerja Mesin Pencacah Tulang Ikan}

Mesin pencacah bekerja berdasarkan mekanisme kerja poros berputar yang dilengkapi dengan sepasang roda gigi untuk memutar sepasang mata pisau dengan sumber penggerak berupa motor listrik 2 HP. Pisau berputar saling berlawanan ke arah dalam secara sinergis untuk mencacah bahan sehingga diperoleh ukuran cacahan yang lebih kecil. Arah putaran dan bentuk pisau yang meruncing ke dalam menyebabkan material yang akan dicacah tertarik dan masuk di celah antara dua mata pisau. Sisi-sisi pisau yang tajam akan mencabik atau mencacah material yang masuk tersebut. Jarak antar pisau juga menentukan hasil cacahan yang diperoleh, jika jarak antar pisau dekat, maka hasil cacahan lebih kecil dan sebaliknya.

\section{Uji Kinerja Mesin Pencacah Tulang Ikan}

Hasil uji kinerja mesin pencacah tulang ikan pada variasi frekuensi inverter 25; 37,5; dan $50 \mathrm{~Hz}$ dengan parameter yang diamati meliputi rendemen, kecepatan putaran poros, waktu pencacahan, dan kapasitas pencacahan disajikan pada Gambar 6 sampai 9. Gambar 6 menunjukkan bahwa rendemen yang diperoleh berkisar antara $88,18-92,69 \%$, di mana rendemen tertinggi terdapat pada perlakuan frekuensi $50 \mathrm{~Hz}$. Hasil analisis statistik menunjukkan bahwa frekuensi inverter tidak berpengaruh terhadap rendemen $(p>0,05)$. Terjadi fluktuasi pada nilai rendemen, di mana hal ini disebabkan proses pengumpanan bahan baku pada hopper masih menggunakan proses manual, sehingga mempengaruhi jumlah masukan bahan baku kedalam

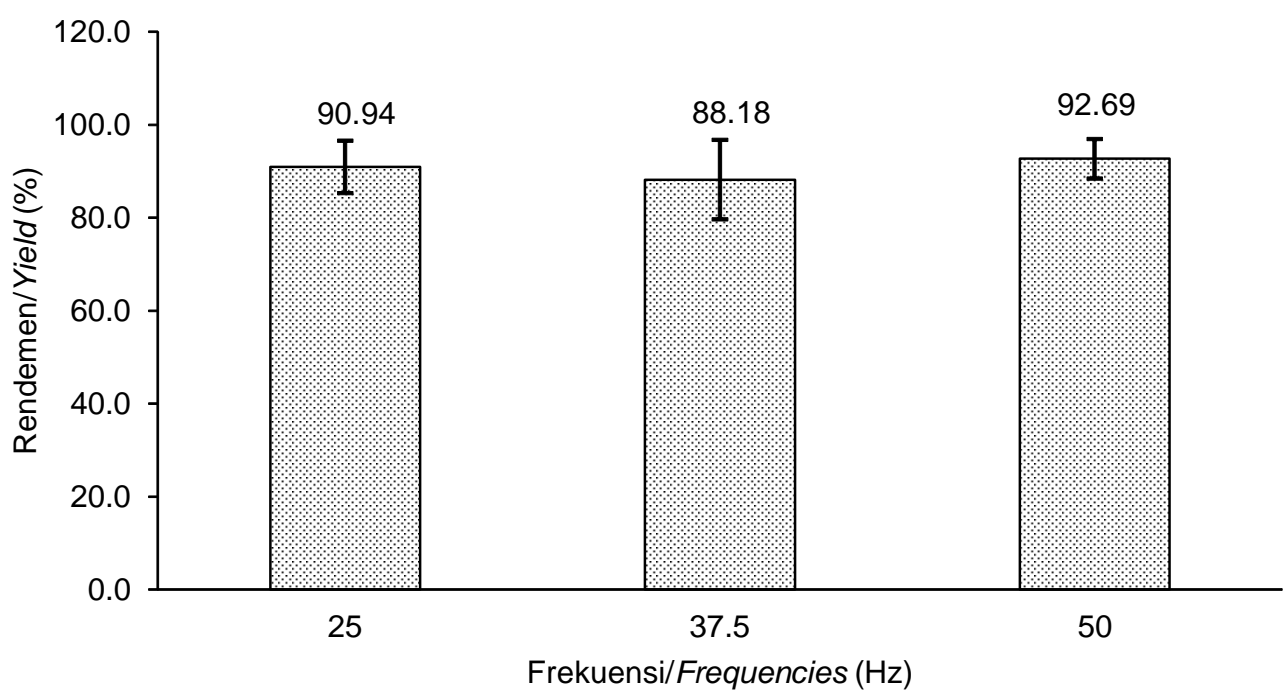

Gambar 6. Pengaruh frekuensi inverter $(\mathrm{Hz})$ terhadap rendemen Figure 6. Effect of inverter frequencies $(\mathrm{Hz})$ on yield 


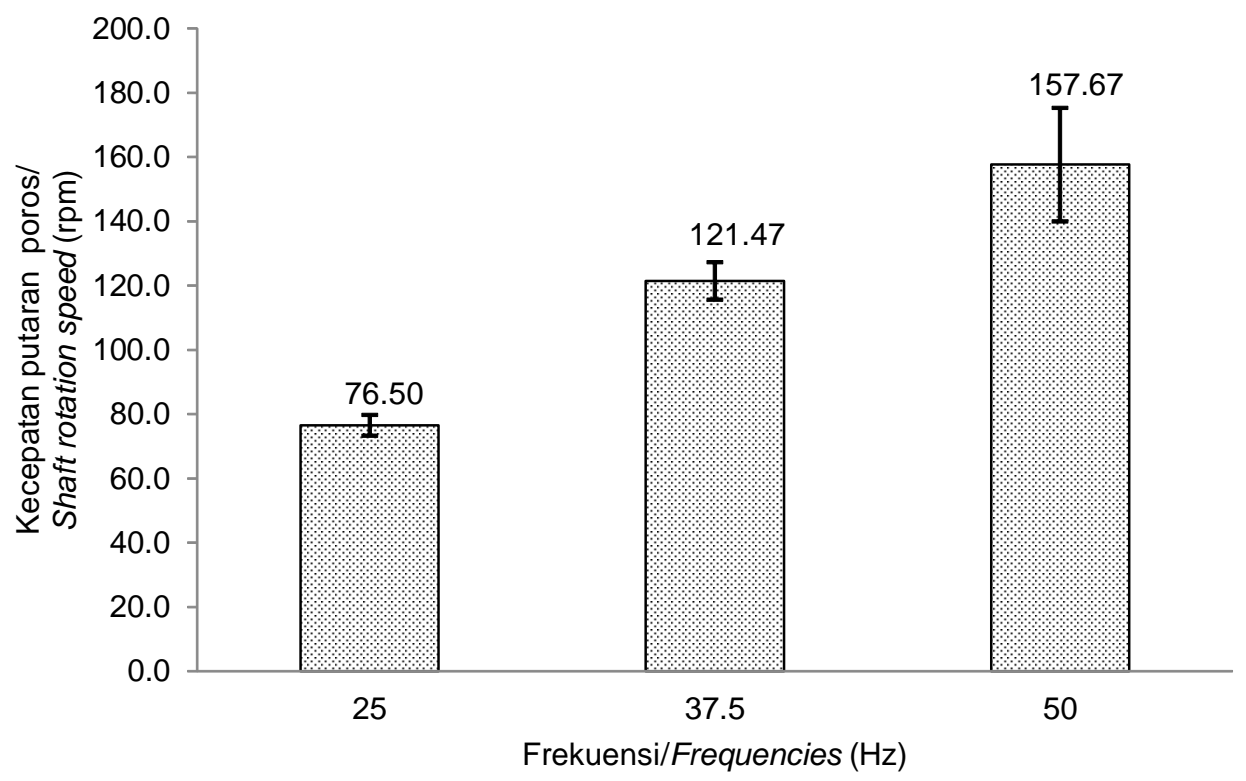

Gambar 7. Pengaruh frekuensi inverter $(\mathrm{Hz})$ terhadap kecepatan putaran poros

Figure 7. Effect of inverter frequencies $(\mathrm{Hz})$ on shaft rotation speed

mesin pencacah dan efeknya mempengaruhi rendemen akhir yang diperoleh.

Gambar 7 menunjukkan bahwa kecepatan putaran poros yang diukur berkisar antara 76,50-157,67 rpm, di mana nilai tertinggi terdapat pada perlakuan frekuensi $50 \mathrm{~Hz}$. Hasil analisis statistik menunjukkan bahwa frekuensi inverter berpengaruh signifikan terhadap kecepatan putaran poros $(p<0,05)$. Waktu pencacahan yang diukur berkisar antara 42,67-167,67 detik, di mana waktu pencacahan tercepat terdapat pada perlakuan $50 \mathrm{~Hz}$ (Gambar 8). Hasil analisis statistik menunjukkan bahwa frekuensi inverter berpengaruh signifikan terhadap waktu pencacahan tulang ikan $(p<0,05)$. Kapasitas pencacahan berkisar antara 69,97-278,69 kg/jam, di mana nilai tertinggi terdapat pada perlakuan frekuensi $50 \mathrm{~Hz}$ (Gambar 9).

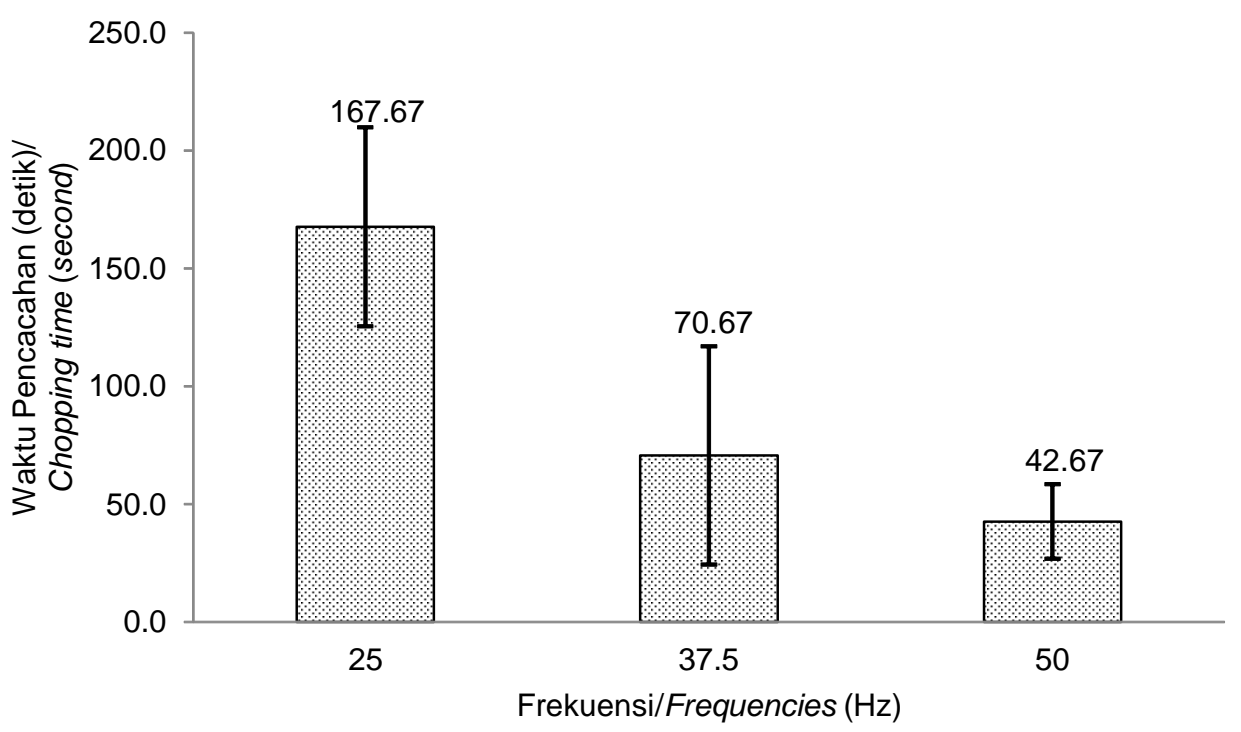

Gambar 8. Pengaruh frekuensi inverter $(\mathrm{Hz})$ terhadap waktu pencacahan Figure 8. Effect of inverter frequencies $(\mathrm{Hz})$ on chopping time 


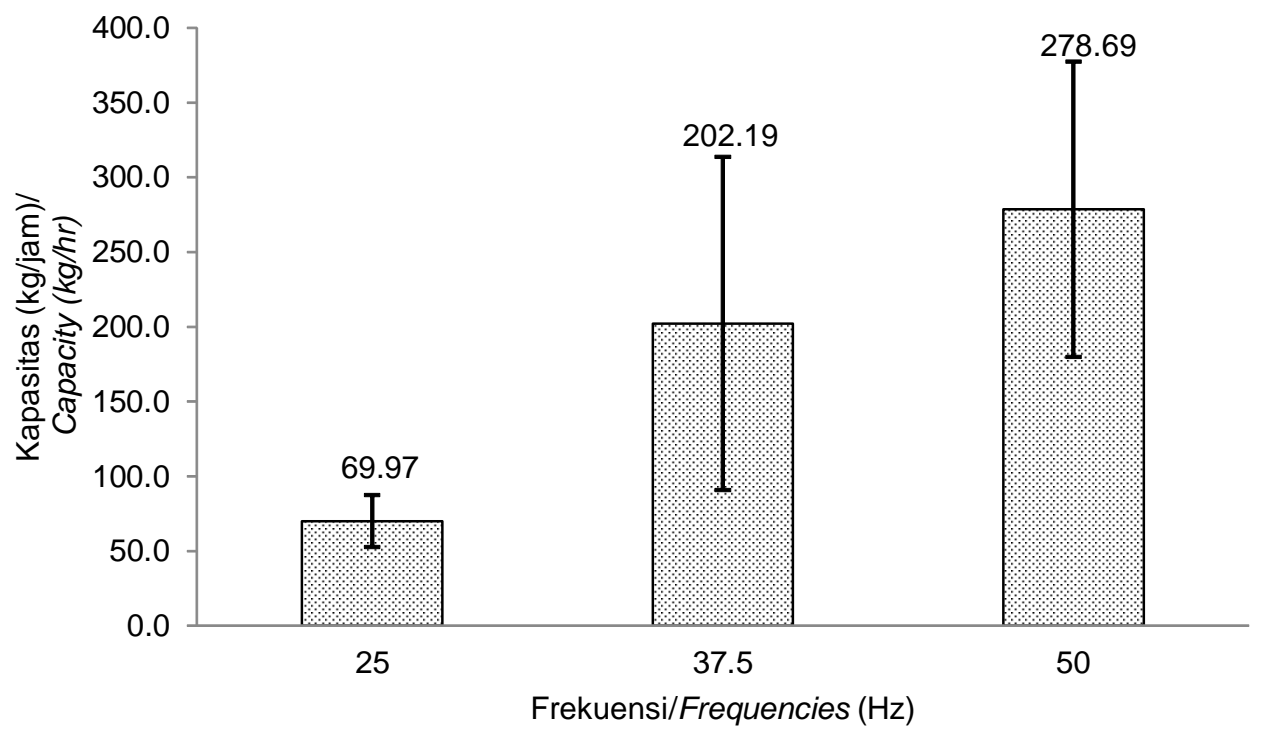

Gambar 9. Pengaruh frekuensi inverter $(\mathrm{Hz})$ terhadap kapasitas

Figure 9. Effect of inverter frequencies $(\mathrm{Hz})$ on capacity

Hasil analisis statistik menunjukkan bahwa frekuensi inverter tidak berpengaruh signifikan terhadap kapasitas pencacahan $(p>0,05)$. Untuk parameter kecepatan putar poros dan waktu pencacahan menunjukkan adanya suatu pola, di mana semakin besar frekuensi inverter, kecepatan putaran poros semakin tinggi dan waktu pencacahan semakin singkat. Hal ini disebabkan karena frekuensi masukan mempunyai hubungan berbanding lurus dengan kecepatan putar motor. Penelitian tentang frekuensi dan kecepatan putar motor juga dilakukan oleh Haryanto (2011) yang menyatakan bahwa perubahan frekuensi masukan motor dapat mengakibatkan perubahan pada kecepatan motor. Semakin besar frekuensi masukan yang diberikan, maka kecepatan motor akan semakin tinggi, dan begitu pula sebaliknya.

Berdasarkan hasil analisis statistik, frekuensi inverter tidak berpengaruh signifikan terhadap kapasitas pencacahan, sedangkan frekuensi inverter memberikan pengaruh signifikan terhadap kecepatan putaran poros dan waktu pencacahan. Kecepatan putaran poros yang semakin naik akan mengakibatkan jumlah atau berat bahan yang tercacah semakin meningkat per satuan waktu, maka seharusnya akan meningkatkan kapasitas pencacahan. Kondisi ini diduga disebabkan karena proses pengumpanan atau pemasukan bahan baku kedalam mesin ketika uji coba tidak stabil yang disebabkan karena pengumpanan masih dilakukan secara manual, belum menggunakan mesin. Selain itu diduga juga disebabkan karena karakteristik bahan baku yang digunakan untuk uji coba tidak seragam.
Berdasarkan rancangan awal, kapasitas yang diharapkan adalah $500 \mathrm{~kg} / \mathrm{jam}$, tetapi dari hasil uji coba menunjukkan kapasitas tertinggi pada frekuensi $50 \mathrm{~Hz}$ adalah sekitar $278 \mathrm{~kg} / \mathrm{jam}$. Hal ini dikarenakan penggunaan gear reducerdengan rasio roda gigi yang besar untuk mendapatkan torsi yang besar, karena salah satu fungsi gear reducer adalah untuk menurunkan kecepatan putaran dan pada saat yang sama menaikan torsi pada sumbu putaran sesuai rasio roda gigi. Penggunaan rasio roda gigi yang besar ini salah satu tujuannya karena hasil uji coba pada beberapa tulang dan kepala ikan yang berukuran besar torsi motor tidak mampu untuk mencacahnya. Oleh karena itu dipilih rasio roda gigi yang lebih besar supaya torsinya meningkat tanpa mengganti daya motor. Selain itu variasi sifat fisik bahan juga diduga mempengaruhi kapasitas pencacahan. Hal ini seperti pernyataan yang disampaikan oleh Mursidi (2015) yang menyatakan bahwa faktor yang mempengaruhi kapasitas kerja mesin pencacah adalah sifat fisik bahan dan perbedaan kemampuan mentransfer tenaga pada perajangan atau pencacahan.

Kapasitas pencacahan terbesar diperoleh pada frekuensi $50 \mathrm{~Hz}$, atau pada putaran motor paling tinggi. Hal ini bersesuaian dengan persamaan 3 yang menunjukkan bahwa daya motor $(P)$ berbanding lurus dengan torsi dan kecepatan sudut motor, sehingga daya maksimal dapat diperoleh pada putaran motor tinggi dan torsi maksimum. Torsi maksimum motor diperoleh pada putaran motor tertentu (Anthony, 2011). Hal ini memberikan dasar yang kuat bahwa semakin tinggi nilai frekuensi, berkorelasi positif dengan daya yang diberikan oleh motor penggerak, sehingga kinerja 
mesin pencacah tulang ikan semakin meningkat. Selain itu dengan meningkatnya putaran motor juga akan meningkatkan jumlah pencacahan per satuan waktu sehingga kapasitas akan naik.

\section{KESIMPULAN}

Telah diperoleh mesin pencacah tulang ikan berpenggerak motor listrik 2 HP dengan mekanisme kerja poros berputar yang dilengkapi sepasang pisau yang berputar saling berlawanan ke arah dalam. Hasil uji kinerja menggunakan bahan baku tulang dan kepala ikan dengan panjang sekitar $15 \mathrm{~cm}$, lebar $8 \mathrm{~cm}$ dan tebal $5 \mathrm{~cm}$ menunjukkan bahwa rata-rata rendemen cacahan dengan output $2-3 \mathrm{~cm}$ dan kecepatan putaran poros pada frekuensi inverter 25,$0 ; 37,5$ dan $50,0 \mathrm{~Hz}$ berturut-turut yaitu $90,94 \%, 88,18 \%, 92,69 \%$ dan $76,50 \mathrm{rpm}, 121,47 \mathrm{rpm}, 157,67 \mathrm{rpm}$. Waktu pencacahan dan kapasitas pencacahan pada frekuensi inverter 25,0; 37,5 dan $50,0 \mathrm{~Hz}$ berturutturut yaitu 167,67 detik, 70,67 detik, 42,67 detik dan $69,97 \mathrm{~kg} / \mathrm{jam}, 202,19 \mathrm{~kg} / \mathrm{jam}, 278,69 \mathrm{~kg} / \mathrm{jam}$. Semakin tinggi frekuensi inverter, kecepatan putaran poros semakin tinggi, waktu pencacahan semakin singkat dan kapasitas pencacahan semakin besar. Hasil uji coba menunjukkan bahwa secara umum mesin pencacah ini menghasilkan kapasitas terbesar pada frekuensi 50,0 Hz.

Pada perancangan dan pengujian kinerja mesin pencacah tulang ikan ini kapasitasnya belum mencapai kapasitas yang ditentukan pada kriteria desain yaitu $500 \mathrm{~kg} / \mathrm{jam}$. Supaya mesin dapat mencapai kapasitas yang diharapkan maka perlu dilakukan beberapa modifikasi. Modifikasi untuk meningkatkan kapasitas adalah dengan menambah daya motor menjadi lebih besar sehingga menghasilkan torsi yang lebih besar dan menggunakan rasio gear reduction yang lebih kecil sehingga putaran mesin akan meningkat. Konsekuensinya adalah daya listrik yang dibutuhkan untuk operasional akan lebih besar.

\section{UCAPAN TERIMA KASIH}

Penelitian ini dibiayai oleh Loka Riset Mekanisasi Pengolahan Hasil Perikanan. Ucapan terima kasih disampaikan kepada Sri Hariyadi, A.Md dan Herman Sulistiyo yang telah membantu pelaksanaan kegiatan penelitian.

\section{DAFTAR PUSTAKA}

Anthony, Z. (2011). Pengaruh Perubahan Frekuensi dalam SistemPengendalian Kecepatan Motor Induksi 3-Fasa
Terhadap Efisiensi dan Arus Kumparan Motor. Jurnal Teknik Elektro ITP, 1(1), 25-29.

Assadad, L., Hakim, A. R., \& Widianto, T. N. (2015). Mutu Tepung Ikan Rucah Pada Berbagai Proses Pengolahan. Prosiding Seminar Nasional Tahunan XII Hasil Penelitian Perikanan dan Kelautan Jilid III, 53-62.

Berutu, N., Hidayat, A., Syahputra, H., \& Harefa, M.S. (2018). Pengolahan Tepung Ikan dari Limbah Ikan di Desa Regemuk Kecamatan Pantai Labu Kabupaten Deli Serdang. Jurnal Pengabdian Kepada Masyarakat, 24(1), 510-515.

David, S., \& Joel, O. O. (2018). Design and Construction of a Plastic Shredder Machine for Recycling and Management of Plastic Wastes.International Journal of Scientific \& Engineering Research, 9(5).

Hande, A. S., \& Deshpande, A. A. (2014). Methodology For Design \& Fabrication of Portable Organic Waste Chopping Machine To Obtain Compost -A Review. International Journal for Innovative Research in Science \& Technology, 1(7), 132-135.

Handoyo, W. T., \& Assadad, L. (2016). Karakterisasi Proses Produksi Dan Kualitas Tepung Ikan di Beberapa Pengolah Skala Kecil. Prosiding Seminar Nasional Tahunan XIII Hasil Penelitian Perikanan dan Kelautan Jilid III, 197-205.

Harris, H., Efreza, D., \& Nafsiyah, I. (2011). Potensi Pengembangan Tepung Ikan dari Limbah Pengolahan Makanan Tradisional Khas Palembang Bebasis Ikan. Jurnal IImu-ilmu Perikanan dan Budidaya Perairan, 6(1), 55-66.

Haryanto, H. (2011). Pembuatan Modul Inverter sebagai Kendali Kecepatan Putaran Motor Induksi. Rekayasa, 6(1), pp. 9-20.

Hidayat, M., Harjono, Marsudi, \& Gunanto, A. (2006). Evaluasi Kinerja Teknis Mesin Pencacah Hijauan Pakan Ternak. Jurnal Enjiniring Pertanian, 6(2), 61-64.

Jadhav, N. D., Patil, A., Lokhande, H., \& Turambe, D. (2018). Development of Plastic Bottle Shredding Machine. International Journal of Waste Resources, 8(2). https:// doi.org/10.4172/2252-5211.1000336

Junaidi, Kasim, A., Zamri, A., \& Anderson, S. (2014). Pengembangan Mesin Pencacah Tandan Kosong Sawit (TKS) dengan Metode Pemotongan Crusher. Poli Rekayasa, 9(2), 42-51.

Kementerian Kelautan dan Perikanan (KKP). (2017). FAQ Penyaluran Bantuan Pemerintah Gerakan Pakan Ikan Mandiri Tahun Anggaran 2018. Retrieved from https://kkp.go.id/artikel/2646-faq-penyaluranbantuan-pemerintah-gerakan-pakan-ikan-mandiritahun-anggaran-2018.

Kementerian Kelautan dan Perikanan (KKP). (2018). Infografis Program Prioritas KKP 2017-2018. Retrieved from http://kkp.go.id/an-component/media/ upload-gambar-pendukung/kkp/Infografis-ProgramPrioritas-KKP-2017-2018.pdf.

Khotimah, B. K., \& Haryanto, B. S. D. (2017). Pemberdayaan Masyarakat Melalui Pembuatan Tepung Ikan dari Limbah Ikan di Kepulauan Talango Sumenep Madura. Jurnal Pangabdhi, 3(1), 20-29. 
Kumar, I. M. S., \& Kumar, T. R. H. (2015). Design and Development of Agricultural Waste Shredder Machine. IJISET - International Journal of Innovative Science, Engineering \& Technology, 2 (10), 164-172.

Kusumo, G. (2012). Bahan Baku Pakan: Indonesia Butuh 150.000 Ton Tepung Ikan Per Tahun. Retrieved from http://industri.bisnis.com/read/20120511/99/76707/ bahan-baku-pakan-indonesia-butuh-150-dot-000ton-tepung-ikan-per-tahun.

Mahendra, C., Assadad, L., \& Zulfia, N. (2015). Potensi Pemanfaatan Udang (Peanaeus sp.) dan Rajungan (Portunus pelagicus) Rucah sebagai Bahan Baku Alternatif Pakan Ikan. Prosiding Seminar Nasional Tahunan XII Hasil Penelitian Perikanan dan Kelautan Jilid III, 157-165.

Mursidi, R. (2015). Desain Perajang Serbaguna dengan Tipe Blade Sliding dan Sistem Transfer Tenaga Semi Mekanis dan Mekanis. Prosiding Seminar Agroindustri dan Lokakarya Nasional FKPT-TPI. 52-57.

Nainggolan, H., Rahmantya, K. F., Asianto, A. D., Wibowo, D., Wahyuni, T., Somad, W. A., \& Zunianto, A. K. (2017). Kelautan dan Perikanan Dalam Angka Tahun 2016. Pusat Data, Statistik dan Informasi Kementerian Kelautan dan Perikanan.
Nurhayat, W. (2013). 75\% Kebutuhan Tepung Ikan Masih Impor. Retrieved from http://finance.detik.com/read/ 2013/12/30/125305/2453938/1036/75-kebutuhantepung-ikan-masih-impor.

Poernomo, A. (2013). Sampai kapan tergantung pada tepung ikan?. Retrieved from http:// achpoer.blogspot.com/2013/02/normal-0-falsefalse-false-in-x-none-x.html.

Pradana, E. W. M. (2015). Rancangbangun Mesin Pencacah Rumput Laut Skala UKM. JRM, 02(02), 1116.

Sedayu, B. B., Erawan, I. M. S., \& Utomo, B. S. B. (2013). Rancang Bangun dan Ujicoba Mesin Pemisah Daging Ikan Berdaya Listrik Rendah. Jurnal Pascapanen dan Bioteknologi Kelautan dan Perikanan, 8(2), 125-132.

Ting, R. P., Casas, E. V., Peralta, E. K., \& Elauria, J. C. (2012). Design, Fabrication, and Optimization of Jatropha Sheller. International Journal of Optimization and Control: Theories \& Applications, 2(2), 113-127.

Weiss, J., George, C., \& Walker, J. (2006). Redesigning an Appropriate Technology Shredder for Manufacture in a Developing Country. International Journal for Service Learning in Engineering, 1(1), 11-26, 